$\xi=-$ 国

\title{
An Analysis of the Bank Employees Domains of Occupational Stress with Reference to Kottayam District, Kerala
}

\author{
$\operatorname{Renji~Issac~}^{1 *}$, V. Krishnaveni ${ }^{2}$ \\ ${ }^{1}$ Ph.D. Research Scholar, Department Of Management, Karpagam Academy Of Higher Education, Coimbatore. \\ ${ }^{2}$ Research Supervisor, Department Of Management, Karpagam Academy Of Higher Education, Coimbatore.
}

\begin{abstract}
Occupational stress is a common phenomenon that is pervasive in every industry. The domains of stress, especially in the banking sector, consist of the demand of inter role performance, role stagnation, role expectation, conflict of role, role erosion, role overload, role isolation, personal inadequacy, role ambiguity, role distance and resource inadequacy. The work stress in the banking industry occurs because of the effects on one's understanding of one's working atmosphere, strengths, opportunities, potential, threats and limitations, while performing a designated role. A gender based study was conducted among 50 bank employees in Kottayam district, Kerala. The gender was taken as an independent variable and stress id taken a dependent variable for the study. The study analysed turbulence, heavy workload and long working hours that have become the norm in the industry. Different elements of stress led to a decline in personal health, relations with colleagues and dissatisfaction with life itself, which affected efficiency and productivity. The study revealed that both the male and female respondents were affected with overload, responsibility, lack of participation, unreasonable work pressure, poor peer relations, intrinsic impoverishment, low status, strenuous working conditions and poor results. The level of significance $(p<.05)$ and the available scores were more that the significance value, except the values of role ambiguity and role conflict.
\end{abstract}

Keywords: Occupational stress, banking sector, bank employees, stressors.

\section{Introduction}

In the banking sector stress is an inevitable factor and most of the employees, both male and female, experienced the occupational stress as an unproductive factor. The bank employees face a great amount of stress while performing their duty. As individuals, they cannot ignore their personal duties and social obligations. The profession demands more than the performance of assigned duties. It results in stress, which is an uncomfortable emotion experienced, often with unpredictable changes, in physiological and behavioral changes. Stress is an output of two variables such as the perception of pressure and the response of the body to the psychological perception and which deals with different systems, metabolism to muscles to memory. Stressor acts a stimulus for stress. Stressors play a major role in one's mood, well-being and behavior. In the banking sector, stressors consist of the demand of inter-role performance, role stagnation, role expectation, conflict of role, role erosion, role overload, role isolation, personal inadequacy, role ambiguity, role distance, resource inadequacy etc. The gender is taken as independent variable and stress id taken as dependent variable for the study. Every organisational role and problems are encountered with Stress. Stress was studied by measuring ten stressors on the employees of the Indian public sector banks, and in the private sector banks.

\section{Statement of the Problem}

The banking organizations demand more productivity and force the employees with an overload of work, often with deadlines. Time-bound work load has both physical and psychological effects on the employees resulting in to trauma. Competition, change in government policies, management strategies and demands on employees' competency also brought a lot of pressure on the employees. Liberalization, privatization and globalization pressurize the executives to deliver service to international standards, without additional resources and training. Those who fail to meet the standard are rated below and often get harassed. The stress sources of the bank employees occur due to individuals inter role distance, role stagnation, role expectation conflict, role erosion, role overload, role isolation, personal inadequacy, role ambiguity, self role distance and resource inadequacy.

\section{Scope of the Study}

The Indian banking industry is turbulent and stormy with heavy workloads, late working hours and different types of customers with different demands. The pressure of work leaves the employees exhausted both physically and mentally. It also affects productivity, efficiency at work, errors in work and relationship with colleagues.

\section{Objectives}

1. To assess the gender based stress among the bank employees.

2. To ascertain different elements of stressor among the bank employees. 


\section{Literature Review}

Manjunatha, M. K. and Renukamurthy, T.P.(2017), conducted a study,with the objective of ascertaining the cause and effect of occupational stress among the bank employees. The bank employees across the world experience stress at work, which have both positive and negative impact. Positive stress increased productivity while the negative stress resulted into unprofitability A majority of the employees could not adapt to the dynamic changes happening in their profession. Conflict in their job role, greater customer demand, constant changes in banking technology and inadequate customer response were treated as the core factor of stress among the bank employees.

Lopes, Caral and Kachalia, Dhara (2016)conducted their study both in private and public banks. Their study showed that the technological advancement had changed the working style of the banking industry, making competition global, causing more stress among the employees. Their study revealed that the association between type of the banks, age, gender and education, job, role, interpersonal relationship contribute significantly to stress. The study recommended that the bank employees should practice new stress absorbing strategies to maintain a good physical and mental health to improve productivity.

Kishori,B., and Vinothini,B. (2016) the authors found that productivity was a decisive factor for the success of any organization. In the highly dynamic and competitive world of today, an employee was exposed to all kinds of stressors that could affect them in all aspects of life. The research intended to study the impact of occupational stress on Nationalized Bank employees.

Das, Priyanka and Srivastav, Alok Kumar(2015)conducted a study to determine the factors of work related stress by different demographic variables among the Bank employees of West Bengal. The findings showed that there was no significant difference in work stress level in terms of demographic factors and there was significant relationship between the organizational factors and the work stress level. According to this study the overall work stress level was moderate among all respondents.

Ementa, Christiana Ngozi(2015)conducted a study to measure the causes of perceived stress among the bank secretaries, the effect stress on the performance and the strategies to cope with it. The study revealed that the secretaries of bank were affected by stress resulting in a fall in productivity. There was a need to adopt strategies to cope with stress. The work of bank secretaries involved many administrative and clerical functions, which created stress.

Kannan, P and Suma,U (2015)were of the view that, in order to manage stress, the organization had to encourage employee development with necessary training as and when required Training, specifically one related to policies and policy implementation, was a key priority. Stress in banking sector was mostly due to excess of work pressure and work life imbalance. The organization should support and encourage taking up roles that help them balance work place and home.

Samartha, Vishal, Begum, Mushtiary et al. (2014) their study stated that stress was an unavoidable thing in banking, as in all occupations. The study revealed that the pressure to perform, lack of planning in the workplace, resistance to change, demands of the family and inadequate capable manpower could put a lot of stress on the executives of bank.

Enekwe, Chinedu Innocent, Agu, Charles Ikechukwu et al. (2014) according to their study, the problem of stress was a gender sensitive issue. Moreover, the bankers' job had a high influence on the technique of stress management in Nigeria.

Rahman, Hasebu, Kamruzzaman et al. (2013)functions of the commercial bank employees caused a lot of stress. The long working hours, work overload, duty towards family, pressure from management, mental depression and insecurity of job were perceived stressors. Employees' wellbeing, both mental and physical, if it was affected by prolonged stress, could lead to depression. An effective job design, a healthy working environment and adequate remuneration should be offered to keep the employees motivated.

Ali ,Tatheer Yawar, Hassan, Atif et al. (2013) the bankers were facing high stress in their job and the reasons for this was stress caused by long working hours, improper reward system, lack of job autonomy, organizational culture, role conflict etc. The main reason was lack of management support. They could notice a number of symptoms indicating high levels of stress. If these symptoms were not noticed early, they could cause serious health problems such as depression, heart problems, diabetes etc.

Sharmila, A Poornima,J (2012) conducted a study among select private banks in Salem, Tamil Nadu regarding the stress of the bank employees. It was found that, exposed to stress, the employees developed many problems including psychological ones. It was the responsibility of the management to take steps to help the staff to overcome the problems and cope with increasing stress.

Bano, Bushara,Jha, Rajiv Kumar et al.(2012)their study was conducted to explore the job-related stress among the public and private sector employees in Uttar Pradesh, India. The ten role stressors and the demographic variables were taken into consideration to assess the stress level. The sample size consisted of 182 public and 120 private sector employees. The study result showed that there was no significant difference in the overall total stress scores between the public and the private sector employees. Awan, Khurram Zafar and Jamil, Faisal et al. (2012) in their research a comparative study was carried out among the permanent executives of Private and Public banks to measure the differences in their total job stress. Some of the variables of public sector bank employees and some other variable affected the private sector bank employees. The overall score found that the public sector bank employees faced more stress.

\section{Profile of the Area}

The Kottayam district is the hub of a number of private and public sector banks in India.

\section{Research Methodology}

This paper aims to ascertain the occupational stress among employees of the bank, Kottayam District, Kerala. This section describes the study in a systematic and scientific way as follows:

\section{Research Design}

The design study was made in accordance with the data collection and analysis. The study consisted of descriptive and exploratory analysis.

\section{Data Collection}

The data was collected from both the primary and the secondary sources. Occupational stress Index was used to collect the research data.

\section{Primary Data}

The opinion of the bank employees working in different banks, both in private and public sector, was collected through the Occupational Stress Index. 


\section{Secondary Data}

Secondary data was gathered from various Publishing sources including Magazines, Journals, Newspapers and Online resources containing past studies on the occupational stress.

\section{Sample Design}

For the study survey sample size was taken, by choosing stratified random sampling. The staffs of the bank consists of those who are in the direct employment at the bank.

\section{Sample Size}

The sample size consisted of 50 bank officials from both the public and private sector banks.

\section{Statistical Tools Used}

The tools used for the analysis are as follows:

i) Standard Deviation

ii) Mean

iii) ' $t$ 'test

Table 1: Distribution of Gender Difference with Population, Mean, SD and ' $\mathrm{t}$ ' value

\begin{tabular}{|c|c|c|c|c|c|}
\hline & Gender & $\mathbf{N}$ & Mean & $\begin{array}{l}\text { Std. } \\
\text { Deviation }\end{array}$ & $\begin{array}{l}\text { 't' } \\
\text { value }\end{array}$ \\
\hline \multirow[t]{2}{*}{ Role overload } & Male & 25 & 15.2800 & 3.61156 & \multirow[t]{2}{*}{$.691^{*}$} \\
\hline & Female & 25 & 17.2000 & 3.59398 & \\
\hline \multirow[t]{2}{*}{ Role ambiguity } & Male & 25 & 10.6000 & 2.17945 & \multirow[t]{2}{*}{$.142^{\prime}$} \\
\hline & Female & 25 & 12.2000 & 2.39792 & \\
\hline \multirow[t]{2}{*}{ Role conflict } & Male & 25 & 14.0400 & 3.07517 & \multirow[t]{2}{*}{$.004^{\prime}$} \\
\hline & Female & 25 & 14.9200 & 2.08006 & \\
\hline \multirow{2}{*}{$\begin{array}{l}\text { Unreasonable group and } \\
\text { political pressure }\end{array}$} & Male & 25 & 10.6000 & 2.59808 & \multirow[t]{2}{*}{.505} \\
\hline & Female & 25 & 11.1600 & 2.99555 & \\
\hline \multirow[t]{2}{*}{ Responsibility for persons } & Male & 25 & 7.7200 & 1.72047 & \multirow[t]{2}{*}{$.591^{*}$} \\
\hline & Female & 25 & 8.2400 & 1.76257 & \\
\hline \multirow[t]{2}{*}{ Under participation } & Male & 25 & 11.2400 & 2.16564 & \multirow[t]{2}{*}{$.727^{*}$} \\
\hline & Female & 25 & 11.6400 & 1.77670 & \\
\hline \multirow[t]{2}{*}{ Powerlessness } & Male & 25 & 8.6400 & 1.43991 & \multirow[t]{2}{*}{$.150^{\circ}$} \\
\hline & Female & 25 & 9.2000 & 1.15470 & \\
\hline \multirow[t]{2}{*}{ Poor peer relations } & Male & 25 & 10.9200 & 2.27156 & \multirow[t]{2}{*}{$.781^{*}$} \\
\hline & Female & 25 & 10.4400 & 2.29274 & \\
\hline \multirow[t]{2}{*}{ Intrinsic impoverishment } & Male & 25 & 11.0800 & 2.41385 & \multirow[t]{2}{*}{.065} \\
\hline & Female & 25 & 11.0800 & 1.91311 & \\
\hline \multirow[t]{2}{*}{ Low status } & Male & 25 & 8.1200 & 1.50886 & \multirow[t]{2}{*}{$.815^{*}$} \\
\hline & Female & 25 & 9.0800 & 1.49778 & \\
\hline \multirow[t]{2}{*}{ Strenuous working conditions } & Male & 25 & 10.2400 & 1.12842 & \multirow[t]{2}{*}{.746} \\
\hline & Female & 25 & 10.6800 & 1.02956 & \\
\hline \multirow[t]{2}{*}{ Unprofitability } & Male & 25 & 5.2400 & 1.58850 & \multirow[t]{2}{*}{$.532 *$} \\
\hline & Female & 25 & 5.0800 & 1.41185 & \\
\hline
\end{tabular}

\section{*Source: Primary Data}

* Significant at 0.05 level

The above table reveals that there is a significant difference between male and female with occupational stress index with respect to their level of Role overload, Role ambiguity, Role conflict, Unreasonable group and political pressure, Responsibility for persons, under participation, Powerlessness, Poor peer relations, Intrinsic impoverishment, Low status, Strenuous working conditions and Unprofitability.

\section{Findings}

- The respondents were equally from the public and private sector banks.

- Majority of the respondents(70 percent) were married.

- The Role overload of male and female with occupational stress scores is more $(t=0.691 ; p>0.05)$.

- The Role ambiguity of male and female with occupational stress scores is more $(t=0.142 ; p>0.05)$.

- The level of Role conflict of male and female with occupational stress scores is less $(t=0.004 ; p<0.05)$.

- The level of Unreasonable group and political pressure of male and female with occupational stress scores is more $(\mathrm{t}=$ $0.505 ; \mathrm{p}>0.05)$.

- The level of Responsibility for persons of male and female with occupational stress scores is more $(t=0.150 ; p>0.05)$.

- The level of under participation of male and female with occupational stress scores is more $(t=0.727 ; p>0.05)$.

- The level of Poor peer relations of male and female with occupational stress scores is more $(t=0.781 ; p>0.05)$.

- The level of intrinsic impoverishment of male and female with occupational stress scores is more or less $(t=0.065 ; p>$ 0.05). .

- The level of Low status of male and female with occupational stress scores is more $(t=0.815 ; \mathrm{p}>0.05)$.

- The level of strenuous working conditions of male and female with occupational stress scores is more $(t=0.746 ; p>$ $0.05)$.

- The level of Unprofitability of male and female with occupational stress scores is more $(t=0.532 ; p>0.05)$.

\section{Conclusion}

Occupational stress is not a myth. Its presence in the professional and individual life among the bank employees is high. The banking firms have to develop tools and techniques to reduce the effects of stress and to mitigate the ill effects of stress. Stress is a factor to be managed to avoid its negative impact. Stress alters the individual, affects his relations with peers, productivity and, on rare occasions, leads to suicide.

\section{Suggestions}

The following are the suggestions:

- The banking organisations must help the employees cope with stress.

- The various stressors will not so much harm, if employees are taught coping strategies and given periodical training

- The mental and physical illness are the result of high stress.

\section{Future scope of the Study}

Studying and measuring Occupational Stress is a mandatory requirement in the ever changing, competitive and complex environment of the banking industry. The job involves handling of multiple roles, excess work load, inter-intra organisational work, group politics etc. There is a need to conduct more studies on the topic of occupational stress among the bank employees. It is needed to develop the policies, techniques and methods of trainings to create an employee friendly atmosphere in the banks.

\section{References}

[1] Manjunatha MK \& Renukamurthy TP, "Stress among Banking Employee-A Literature Review", International Journal of Research - Granthaalayah, Vol.5, No.1,(2017), pp.206-213. 
[2] Lopes C \& Kachalia D, "Impact of job stress on employee performance in banking sector", International Journal of Science Technology and Management, Vol.5, No.3,(2016), pp.901-913.

[3] Kishori B \& Vinothini B, "A Study on Work Stress among Bank Employees in State Bank of India with Reference to Tiruchirapalli", International Journal of Management and Commerce Innovations, Vol.4, No.1,(2016), pp.201-203.

[4] Das P \& Srivastav AK, "A Study on Stress among Employees of Public Sector Banks in Asansol, West Bengal", International Journal of Science and Research, Vol.4, (2015), pp.108-113.

[5] Ementa, CN, "Secretaries' Perceived Strategies for Coping with Occupational Stress in Banks in Anambra State", An International Multidisciplinary Journal, Vol. 9, No.3, (2015), pp.88-98

[6] Kannan P \& Suma U, "Managing Stress Among Co-Operative Bank Employees In Palakkad District", International Journal of Scientific Engineering and Applied Science, Vol.1, No.7, (2015), pp.132-137.

[7] Samartha V \& Begum M, "A comparative analysis of occupational stress among the employees in public and private sector banks in dakshina kannad district", Bank management, Vol.2, No.2,(2014).

[8] Enekwe CI, Agu CI \& Nnagbogu EK, "Stress Managemen Techniques in Banking Sectors in Nigeria", IOSR Journal of Business and Management, Vol.16, No.7, (2014), pp.33-38

[9] Rahman H, "Perceived Intensity of Stress Stressors: A Study on Commercial Bank in Bangladesh", Asian Business Review, Vol. 3, No.3,(2013), pp.40-43.

[10] Ali TY, Hassan A \& Ali T, "Stress management in private banks of Pakistan", Journal of Emerging Trends in Economics and Management Sciences, Vol.4, No.3,(2013), pp.308-320.

[11] Sharmila A \& Poornima J, "employee stress management in selected private banks in Salem", Elixir International Business Management, Vol.42A, (2012), pp.6555-6558.

[12] Bano B \& Jha RK, "Organizational Role Stress among Public and Private Sector Employees: A Comparative Study", The Lahore Journal of Business, Vol.1, No.1,(2012),pp.23-36.

[13] Awan, KZ \& Jamil F, "A comparative analysis: differences in overall job stress level of permanent employees in private and public sector banks", International Journal of Economics and Management Sciences, Vol.1, No.10,(2012), pp.45-58. 